\title{
Morphophysiological Responses of Common Bean (Phaseolus vulgaris L.) Genotypes to Water Stress
}

\author{
Philip Kalima, David M. Lungu and Mebelo Mataa* \\ School of Agricultural Sciences, Department of Plant Sciences, University of Zambia, P. O. Box 32379, \\ Lusaka, Zambia. \\ Corresponding author* \\ School of Agricultural Sciences, Department of Plant Sciences, University of Zambia, P. O. Box 32379, \\ Lusaka, Zambia. Email: shogun.meb@gmail.com
}

DOI: https://doi.org/10.53974/unza.jabs.5.1.611

\begin{abstract}
The yield of common bean (Phaseolus vulgaris $\mathrm{L}$.) is highly constrained by water deficit, especially during reproductive development. The purpose of the study was to determine the association of the morphophysiological traits with water stress and how this affects grain yield in common beans. A field experiment involving eight common bean genotypes and three water regimes $(50 \%, 75 \%$, and $100 \%$ of crop evapotranspiration) was conducted at the National Irrigation Research Station, Mazabuka District, during the 2012 growing season. A splitplot design, with four replications was used; with soil moisture regime (main plot) and the genotypes (subplot). Based on variation in water stress tolerances, 8 test genotypes - Gadra, KE 3, KE 4, ZM 4488, SER 76 SER 180, SER 89 and CAR-ZAR were used. Water stress treatments were imposed at the preflowering stage and were discontinued after forty-three days when the crop was in its late reproductive stage.

Significant differences were found among genotypes for Chlorophyll $a$ $(\mathrm{Chl} a$ ), chlorophyll $b(\mathrm{Chl} b)$, Total chlorophyll, relative water content, grain yield, number of pods per plant, seed weight, seeds per pod and days to 50 per cent flowering under the three water stress conditions. The grain
\end{abstract}

yield in normally irrigated conditions $\left(2191.3 \mathrm{~kg} \mathrm{ha}^{-1}\right)$ was 60 per cent higher than in high water stress conditions $\left(866.2 \mathrm{~kg} \mathrm{ha}^{-1}\right)$, while in the low water stress conditions $\left(1078.3 \mathrm{~kg} \mathrm{ha}^{-1}\right)$, the reduction in grain yield was 50.8 per cent. There was a significant genotype by the environment, showing that the genotypes behaved differently under the different growing conditions. Results suggested that Gadra, KE 4, ZM 4488, and SER 180 were water stress tolerant while the SER 89, CAR-ZAR, KE 3 and SER 76 were water stress-sensitive genotypes. These results suggest that a selection method based on $100 \mathrm{SW}$, Chl a, Chl b, and NPP can be used in breeding for bean genotypes to water stress.

Keywords: cell membrane thermostability, chlorophyll, drought susceptibility index

\section{Introduction}

Under the context of global climate change that has, among other effects, seen reduced and unpredictable rainfall patterns, crop productivity, particularly among smallholder farmers, has fallen. Therefore, studies centering on improved water use efficiency are critical for ensuring food security, particularly, for the rural poor. 
Common Beans (Phaseolus vulgaris L.) is one of the important grains for human alimentation and is worldwide planted on approximately twenty-six million hectares [1]. It is the second most important source of dietary protein, and the third most important source of calories for low-income African households after cassava and maize $[2,3]$. Beans are second to groundnuts among the food legume crops grown in Zambia in terms of economic importance [3,4]. Plants development and productivity is adversely affected by biotic and abiotic stress $[5,6,7]$. Productivity of beans is generally low, with a global average yield of $715 \mathrm{~kg} \mathrm{ha}^{-1}$ against a potential yield of 1,500 to $3,000 \mathrm{~kg} \mathrm{ha}^{-1}$.

In Africa, the average yield is about $500 \mathrm{~kg} \mathrm{ha}^{-1}$ which is well below the potential global yield [8]. This low productivity is due to both biotic and abiotic factors among which, water stress and low soil phosphorus are perhaps the major factors limiting crop production worldwide, ranked only second to pest and disease infestation [9]. The production of beans is usually under rainfed conditions, and insufficient or unpredictable rainfall limits the yield [10]. In Zambia, the bulk of bean production is by smallscale farmers, who depend entirely on stored soil moisture and rainfall for crop production. During the growing season, intermittent and, or terminal droughts are experienced. This situation is expected to worsen with the emergence of extreme climate change. Soil water deficits severely retard plant development, reducing yield. It is reported that 60 per cent of common bean production is located in drought-prone areas, and the increasing competition with major crops continues to push common beans into marginal lands with an increased risk of drought stress [11]. Adoption of effective cultural and management practices can reduce yield losses even in water-deficient environments, but irrigation facilities are costly and beyond the reach of scale farmers.

Suriyagoda et al., (2014), reviewed and analysed how plants respond to the twin effects of low soil moisture and phosphorus environments - a common occurrence in the tropics that severely retard bean yield [12]. This metaanalysis is informative and timely because it looks at crop improvement under the changed climate scenario. Drought tolerance is defined as the relative yield of a genotype compared to other genotypes subjected to the same drought stress [13]. Improving drought tolerance, in cultivated species, has been, for a long time, a major objective for most of the breeding programmes [14]. Intensive studies have been carried out in order to identify factors involved in drought tolerance, which can be used as a criteria for selection [14]. Progress in improving common bean cultivars for dry environments of the tropics, has traditionally been achieved by yield testing of large collections over several locations and years. However, it is a slow, laborious, and expensive process because of the need to assess the yield of large numbers of lines across several locations and years, and the substantial variation 
from the effects of environmental error, seasonal climatic factors, and genotypeenvironment interactions [15]. Therefore, identification of main physiological processes determining yield, by comparing genotypes differing in drought tolerance using rapid and low-cost assessment tools is most desirable [16]. Heat stress and drought have similar effects on the plant cell, damaging the selective permeability of the plasma membrane and making the cell unable to maintain its internal composition due to electrolyte leakage [17].

Cell membrane stability measures cellular electrolyte leakage (as a result of stress) and is one sub-trait that has been used to study drought and heat stress and subsequently, select tolerant genotypes $(14,17)$. In addition to the cell membrane, the thylakoid membrane is one of the first components of the photosynthetic apparatus to be damaged by stress [17]. The ability of thylakoid membranes, which contain carriers for electron transport and photosystems I (PSI) and II (PSII) to resist heat damage, varies among varieties and species. Thus, in developing bean genotypes with high productivity under water stress conditions, elucidating the relationship between the morphophysiological traits and yield and related yield components is essential in developing quick and cost-effective selection criteria. The purpose of the study was to determine the association of the morphophysiological traits associated with water stress and how they relate to grain yield in common beans. Such information can be useful in developing indirect selection criteria for water stress conditions.

\section{Materials and Methods}

The study was conducted at the National Irrigation Research Station $\left(15^{\circ} 45^{\prime} \mathrm{S}\right.$ and $27^{\circ} 56^{\prime} \mathrm{E}$ ), situated in Mazabuka Southern Province of Zambia, from September to December in 2012. Eight physiologically and morphologically diverse bean (Phaseolus vulgaris L.) genotypes Gadra, KE 3, KE 4, ZM 4488, SER 76 SER 180, SER 89 and CAR-ZAR, obtained from the National Seed Control and Certification Institute were used in the study. They were chosen based on their variation in water stress tolerances. The trial was laid out in a split-plot design replicated four times. Water regime treatments based on crop evapotranspiration 50 per cent (high stress), 75 per cent (moderate stress), and 100 per cent (normal irrigation) were assigned to main plots, and common bean genotypes were assigned to the subplots. Water stress was imposed at the pre-flowering stage (V8) and discontinued when the plants were in their late reproductive stage -R8 (18). Planting was done on the 6 September 2012, with a basal dressing fertiliser applied at the time of planting at the rate of $20 \mathrm{~kg} \mathrm{~N}, 40 \mathrm{~kg}$ $\mathrm{P}_{2} \mathrm{O}_{5}$ and $20 \mathrm{~kg} \mathrm{~K} \mathrm{~K}_{2} \mathrm{O}$ per Ha. Thirteen seeds were planted per $2 \mathrm{~m}$ row, giving a total of thirty-nine plants per plot. Normal agronomical practices for growing common bean were followed. An irrigation interval of seven days was used. Ordinary water meter was connected to the main water line, and water was applied using the flooding method. Data was collected on morphological and physiological traits as well as on yield and yield components. 


\section{Chlorophyll Content}

Chlorophyll was extracted by grinding the macerated pieces of leaves from fully expanded photosynthesing leaves, at the mid flowering period, obtained from randomly selected plants in the middle row of each plot [19]. About $0.1 \mathrm{~g}$ of material was ground in $10 \mathrm{ml}$ of 80 per cent acetone (acetone: water; $80: 20 \mathrm{v}: \mathrm{v})$. The leaf homogenate was then filtered through a Whatman filter paper. The retentate was removed by the filter paper and discarded while the extract was collected in a test tube. The absorbance of the extract was determined at 663 and $645 \mathrm{~nm}$. Total chlorophyll (Total Chl) contents, Chlorophyll $a(\mathrm{Chl} a)$ and chlorophyll $b(\mathrm{Chl} b)$, were calculated by using the equations of Arnon [19].

Chl $a(\mathrm{mg} \mathrm{g}-1)=[(12.7 \times \mathrm{A} 663)$

- $(2.6 \times \mathrm{A} 645)] \times \mathrm{ml}$ acetone $/ \mathrm{mg}$ leaf tissue.

Chl $b(\mathrm{mg} \mathrm{g}-1)=[(22.9 \times \mathrm{A} 645)-$ $(4.68 \times \mathrm{A} 663)] \times \mathrm{ml}$ acetone $/ \mathrm{mg}$ leaf tissue.

Total Chl $=\mathrm{Chl} a+\mathrm{Chl} b$.

\section{Relative Water Content}

Relative Water Content (RWC) was determined from two fully expanded leaves of randomly selected plants from the middle row of the plot [20]. The leaves were weighed to get the Fresh Weight (FW), then soaked in distilled water in a petri dish and kept in the dark at $10^{\circ} \mathrm{C}$ for twenty-four hours. They were then weighed to get the Turgid Weight (TW). The leaves were then dried in an oven at $70^{\circ} \mathrm{C}$ for forty-eight hours to get the Dry Weight (DW). The RWC was calculated as follows;

$$
\mathrm{RWC}=(\mathrm{FW}-\mathrm{DW}) /(\mathrm{TW}-\mathrm{DW}) \times 100
$$

\section{Drought Susceptibility Index}

The Drought Susceptibility Index (DSI) predicted the performance of a line grown under stressed and non-stressed conditions. The DSI for each genotype used in the study was calculated according to Fischer and Maurer (21). The DSI = $(1-\bar{Y} s / \bar{Y} p) / D I I$, where $(1-\bar{Y} s / \bar{Y} p)$ is the stress index and $\bar{Y} s$ and $\bar{Y} p$ are mean of all genotypes under stress and non-stress conditions, respectively. The geometric mean was calculated according to Kaiser [22] et al.

\section{Data Analysis}

Data was analysed using GenStat Discovery Version 14. Data was subjected to Analysis of Variance (ANOVA) to determine significant differences among treatments for various parameters. Means of the treatments that exhibited significant differences, were separated using the Least Significant Difference (LSD) test. Relationships between selected parameters were determined using Pearson's simple correlation test. Stepwise multiple regression was used to determine the morphophysiological traits that accounted for the largest proportion of variation among lines across environments, and SPSS was used [23].

\section{Results}

The analysis of variance revealed highly significant differences $(\mathrm{p} \leq$ 0.001 ) in treatment responses among the eight genotypes used in the study. Water regime had significant effects on most parameters except plant height (PHT), number of pods per plant (NPP) and number of seeds per pod (NSP). Highly significant interactions between genotypes and water regimes for all traits measured were also observed (Table 1). 


\section{Effect of Water Stress on Morphophysiological Traits}

The effects of genotype and water stress on morphophysiological parameters are shown in Table 2. Highly significant differences among genotypes for water regime $(p \leq 0.001)$ were observed in morphophysiological parameters. In terms of Cell Membrane Thermostability (CMT), significant differences between the normal, moderate and high stressed conditions were observed. For the normal water regime, CAR-ZAR at 77.1 per cent and KE 4 had the highest CMT, and the lowest was seen in Gadra (56.8\%). At high stress, Gadra and SER 180 had the lowest CMT, 57 per cent. KE 3 and ZM 4488 maintained the highest CMT, whether under low or high stress. ZM 4488, KE 3 and KE 4 maintained high CMT (over 84\%) under stress.

In terms of chlorophyll content, water stress significantly reduced total chlorophyll, Chl $a$ and $b$. Overall, ZM 4488 had the highest chlorophyll content $\left(52 \mathrm{mg}^{-1} \mathrm{~g}^{-1}\right)$, followed by KE 3

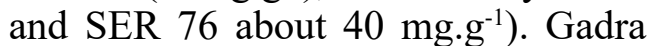
had the least total Chlorophyll (24.3 mg. $\mathrm{g}^{-1}$ ) followed by CAR-ZAR and SER $76 \quad$ (34.5 $\quad \mathrm{mg}^{-\mathrm{g}^{-1}}$ ). Applying water stress reduced the total amount of chlorophyll. Under the low water stress, the highest total chlorophyll reduction was in ZM 4488 (48\%) and KE $4(46 \%)$, followed by CAR- ZAR $(50 \%)$. The least decline under low water stress was KE $4(3 \%)$, Gadra (6\%), followed by SER 76 (14\%).

High water stress caused large reductions in total chlorophyll content. SER 89 had a 78 per cent reduction, followed by KE $4(67 \%)$ and Gadra (48\%) and CAR-ZAR (50\%). Among the genotypes, $\mathrm{KE} 3$ maintained the highest level of Chlorophyll at high water stress (74.4\%).
Water stress altered the ratios of Chl $a$ to $\mathrm{Chl} b$. Under a normal water regime, all the genotypes had less $\mathrm{Chl}$ $a$ compared to $\mathrm{Chl} b$. The ratio ranged from 39 per cent in ZM 4488, 45 per cent (CAR- ZAR) to 78 per cent in KE 3. KE 4 and Gadra maintained almost equal proportions of $\mathrm{Chl} a$ and $b$. Under water stress, the ratio of Chl $a$ to $b$ fell in most genotypes (SER 89, SER 180, KE 3 and Gadra). Under high water stress, the proportion of chl $a$ to $b$ reversed to show a slight increase, but it was still lower than the normal watered treatments.

The treatments exerted significant effects on plant height (Table 2). Plant height in the high stress regime $(19 \mathrm{~cm})$ was 38.7 per cent lower than the optimum water regime $(31 \mathrm{~cm})$. For the moderate water stress, at $24 \mathrm{~cm}$, the reduction relative to the optimum water regime was 22.6 per cent. The RWC declined with water stress, and the rate increased with the severity of water stress. KE 4 and SER 180 and ZM 4488 being more sensitive to water stress, and SER 76 being least sensitive in terms of RWC.

\section{Effect of Water Stress on Grain Yield and Yield Components}

There were highly significant differences in grain yield among the different genotypes (Table 1 and Table 3 ). The mean grain yield across all genotypes was $2191.2 \mathrm{~kg} \mathrm{Ha}^{-1}$ (Table 4). The yield varied from $1433 \mathrm{~kg} \mathrm{Ha}^{-1}$ (SER 180) to $4364 \mathrm{~kg} \mathrm{Ha}^{-1}$ (SER 76). The highest grain yield was obtained from SER $76\left(4363.7 \mathrm{~kg} \mathrm{Ha}^{-1}\right)$ followed by KE 3 $\left(2489.6 \mathrm{~kg} \mathrm{Ha}^{-1}\right)$, then KE $4(2236.3 \mathrm{~kg}$ $\mathrm{Ha}^{-1}$ ), CAR-ZAR (1741 kg Ha${ }^{-1}$ ), and the least with SER $180\left(1433.8 \mathrm{~kg} \mathrm{Ha}^{-}\right.$ $\left.{ }^{1}\right)$. The effects of genotype on yield components were highly significant 
for hundred seed weight (100 SW), days -to - 50 per cent (DTF 50\%), and NPP, and they were significant for NSP (Table 1). KE 4 recorded the highest $100 \mathrm{SW}$ of $43 \mathrm{~g}$, while SER 76 recorded the lowest $100 \mathrm{SW}$ of $24 \mathrm{~g}$ in the 50 per cent water regime. SER 180 recorded the NPP [23], followed by SER 76 [30] and GADRA [22], and the lowest NPP was obtained from CAR-ZAR [12] in a 50 per cent water regime. The highest NSP was 5.0 and the lowest NSP was 4.0 and was obtained from seven genotypes in a 50 per cent water regime (Table 3 ). There were highly significant differences among the genotypes for DTF 50 per cent flowering. KE 4, CAR-ZAR, gadra, KE 3 and SER 76 took the longest period (50 days) to reach 50 per cent flowering. SER 180 took the shortest period (35 days) to reach 50 per cent flowering, followed by SER 89 (36 days), ZM 4488 (36 days) in a 50 per cent water regime (Table 3 ).

The reduction in the amount of water applied to the plants did not significantly affect PHT, NPP and NSP. However, it affected the $100 \mathrm{SW}$ significantly (Table 1$)$. In the 50 per cent water regime $(31 \mathrm{~g})$, the reduction in $100 \mathrm{SW}$ was 31.1 per cent from the optimal water regime $(100 \%)$, while in the 75 per cent water regime ( $45 \mathrm{~g})$, the reduction in $100 \mathrm{SW}$ was 11.1 per cent.

\section{Comparison of Seed Yield in Stressed and Non-stressed Environments}

The genotypes gadra, KE 4, ZM 4488, and SER 180 had the lowest DSI (Table 4$)$ of less than a unit $(0.3,0.5$, 0.9 and 0.9 respectively), whereas the genotypes SER 89, CAR-ZAR, KE 3 and SER 76 had higher DSI values higher than a unit $(1.1,1.1,1.2$ and 1.3 respectively). gadra had the lowest $\mathrm{PR}$ (19.11\%), followed by KE 4 (32.96\%) and $\mathrm{ZM} 4488(53.52 \%)$. gadra, KE 4 and ZM 4488 had GM of 1467.7, 1831.1 and 1179.2 , respectively.

\section{Stepwise Regression}

The morphophysiological traits and seed yield were used as independent and dependent variables respectively. A small and significant contribution to total variations was observed among the independent variables in the study. These ranged from $100 \mathrm{SW}$ to $\mathrm{NN}$. $100 \mathrm{SW}$ had a significant influence on grain yield explaining 37.3 per cent of the total variation (Table 6). Other variables (Chl $a, \mathrm{Chl} b, \mathrm{NPP}$ and NN) showed significant contributions to total variation expressed as $\mathrm{R}^{2}$ from 37.3 per cent to 30 per cent. Further additions of other variables to the model did not amount to significant difference thus, not included in the model.

\section{Relationship among \\ Morphophysiological Traits, Grain Yield and Yield Components of Eight Bean Genotypes}

The results showed that all the traits measured were positively and significantly correlated to grain yield except for $\mathrm{Chl} b\left(\mathrm{r}=-0.41^{* *}\right)$ which had a negative correlation. A strong positive correlation was recorded for $100 \mathrm{SW}\left(\mathrm{r}=0.41^{* *}\right)$, Chl $a(\mathrm{r}=$ $\left.0.57^{* *}\right)$ and NPP $\left(\mathrm{r}=0.36^{*}\right)$. Strong positively and significantly inter component correlation between components were observed. Moderate positive correlations were observed between $100 \mathrm{SW}$ and DTF 50 per cent flowering $\left(\mathrm{r}=0.46^{* *}\right)$, Chl $b$ and $\mathrm{Chl}$ $a\left(\mathrm{r}=0.44^{* *}\right)$, RWC and NPP $(\mathrm{r}=$ $\left.0.47^{* *}\right), \mathrm{Chl} b$ and $100 \mathrm{SW}\left(\mathrm{r}=0.36^{*}\right)$, 
NSP and DTF 50 per cent to flowering $\left(\mathrm{r}=0.3^{*}\right)$, NPP and $\mathrm{Chl} b\left(\mathrm{r}=0.39^{*}\right)$, RWC and PHT $\left(r=0.34^{*}\right.$ and NSP and DTF 50 per cent flowering $(r=0.3 *)$.

A weak and positive correlation was observed between $\mathrm{NN}$ and $100 \mathrm{SW}(\mathrm{r}$ $\left.=0.28^{*}\right)$. A strong negative correlation was observed between $\mathrm{Chl} a$ and 100 $\mathrm{SW}\left(\mathrm{r}=-0.41^{* *}\right)$, Chl $b$ and DTF 50 per cent flowering $\left(r=-0.35^{*}\right)$, RI per cent and $\mathrm{NN}\left(\mathrm{r}=-0.34^{*}\right)$ and RI per cent and NSP $\left(-0.39^{*}\right)$.

\section{Discussion}

The effects of water stress, like all other stresses, depends on the plant development stage, the stress applied, the degree and the duration of the stress $(6,7)$. In the current study, plants were subjected to three levels of water stress during the reproductive stage. The results showed wide variation in the responses of the eight genotypes to morphophysiological traits, grain yield and yield components. A marked genotypic variability in traits measured, was observed among the different genotypes. Water stress negatively impacted important morphophysiological traits, grain yield and yield components in all the genotypes tested. The result showed significant differences in comparing the performance of genotypes in the high stress and normally irrigated conditions.

Photosynthetic efficiency depends largely on the quantity and quality of main photosynthetic pigments, including Chl $a$ and $\mathrm{Chl} b$ and accessory pigments which play important roles in photochemical reactions of photosynthesis [24]. The current study showed significant differences among genotypes for $\mathrm{Chl} a$, Chl $b$ and total chlorophyll, especially after being subjected to water stress. There was a general decrease in the leaf chlorophyll content in all the genotypes subjected to water stress. The decrease in chlorophyll content, across all the genotypes in the study, was more in high water stress conditions than in the low water stress or normally irrigated conditions.

The ratio of Chl $a$ to $\mathrm{Chl} b$ is an indicator of the functional integrity of photosynthetic pigment apparatus, and it is known that the light-harvesting complex around photosystem II contains more chlorophyll $b$ [25]. One consequence of water stress is the decrease in total chlorophyll content and the resultant effect of reduced photosynthesis and dry matter production [25]. Photosynthesis, especially the electron transport chain of PSII, is especially sensitive to hightemperature stress. The decrease in photosynthesis under heat stress is associated with damage to the PSII electron transport capacity [14]. The highest decrease in total chlorophyll content was obtained from SER 89 in the high water stress conditions. Baroowa and Gorgio (2012), working with Black gram and Green gram, found that chlorophyll content decreased with the intensity of water stress, indicating that photosynthetic pigments are sensitive to water stress [26]. A reduction in chlorophyll content was reported in other drought-stressed crops such as cotton [27]. The reduction in leaf chlorophyll content under drought has been reported to cause excessive swelling of chloroplast membranes, distortion of lamellae vesiculation, and lipid droplets' appearance [28]. This degradation is 
considered one of the consequences of drought stress resulting from sustained photo-inhibition and photolysis [29]. The decrease in chlorophyll content of leaves under water stress can also be attributed to inhibited chlorophyll synthesis $(30,31)$.

Water stress decreased the RWC of all genotypes in the stressed environments by 13.8 per cent in the high water stress and 1.1 per cent in the low water stress (Table 5). SER 89, SER 180, SER 76 exhibited higher RWC while genotypes gadra, KE 4 had lower RWC. Jiang et al., (32) showed that RWC was an integrative indicator of internal plant water status under drought conditions, and it can be used to identify drought-resistant genotypes. According to Kumar et al. (33), high yielding bean cultivars displayed a smaller reduction in leaf water content than the poor yielder. However, in the present study, the genotypes with low RWC had higher grain yield in a water stress environment than those with high RWC. This could probably be attributed to the stage at which water stress was applied-the seed filling phase. There were highly significant differences in grain yield among the different genotypes (Table 1). The mean grain yield across all genotypes was $2191.2 \mathrm{~kg} \mathrm{ha}^{-1}$. The yield varied from $1741 \mathrm{~kg} \mathrm{ha}^{-1}$ to $4363.7 \mathrm{~kg} \mathrm{ha}^{-1}$. The high yield exhibited by SER 76 and KE 4 for both conditions could be attributed to high NPP, 100 SW, RWC, Chl $a$ and $b$ content and total Chl. The low yield exhibited by genotypes CAR-ZAR and SER 180 could be attributed to negative effects on physiological components low Chl $a$ and $b$ content and RWC. This was translated to low yields arising out of diminished yield components- NPP and 100 SW. The findings in this study agree with Molina et al., (34) who reported a reduction in grain yield and mean weight of hundred seeds of common bean following water stress. The reduction in grain yield could also be attributed to a lower percentage of pod production when the water stress occurs during flowering [35] and from embryos abortion when the water stress occurs during the pod filling stage.

Water stress affected the seed weight of the bean genotypes, and this observation was in agreement with what other researchers found (36). Teran and Singh reported that drought stress reduced common bean 100 SW by 13 per cent on average. In the present study, high water stress reduced $100 \mathrm{SW}$ by about 31.1 per cent, while in low water stress conditions, the reduction in $100 \mathrm{SW}$ was 11.1 per cent. Barrios et al., (37) reported that seed yield reduction of up to 60 per cent observed in common beans under drought stress was attributed to losses of 63.3 per cent in NPP, 28.9 per cent in NSP and 22.3 per cent in seed weight.

The genotypes gadra, KE 4,ZM 4488, and SER 180 in the high water stress conditions had the lowest DSI values, which can be considered as genotypes with low drought susceptibility and high yield stability in both conditions, whereas the genotypes SER 89, CAR-ZAR, KE 3 and SER 76 with DSI values higher than the unit can be identified as high drought susceptibility and poor yield stability genotypes. Agili et al., (38) had similar results using GM and MP parameters and DSI, suggesting that the three parameters could be used to select 
drought-tolerant genotypes. The effects of Cell membrane thermostability on plant performance did not show a consistent relationship to yield. Whereas CAR-ZAR (77\%) and KE 4 (71\%) had high CMT under normal conditions, under water stress (low) ZM 4488 (100\%), SER 180 (93\%), KE 3 (99\%), and KE 4 (86\%) maintained their CMT. However, the highest yields were obtained in SER 76, KE 3 and KE 4. This poor correlation between CMT and yield has been shown by other workers $(14,16,17)$.

ZM 4488 and SER 89, and SER 180 had the highest chlorophyll content. Gadra, SER 76 and KE 3 were able to maintain high Chlorophyll at low water stress, but only KE 3 and SER 180 maintained high chlorophyll content at high water stress. However, at low water stress, only Gadra, ZM 4488, SER 89 and SER 180 had comparatively high grain yield. At high water stress Gadra, KE 4 and ZM 4488 had comparatively high yields. Although the researchers did not measure photosynthetic rate, the ability to accumulate and maintain high chlorophyll content could be used as a proxy for total photosynthesis and, therefore, dry matter synthesis. The results showed that there was no clear relationship between chlorophyll content (and, therefore, photosynthesis) and yield. Better correlations of morphophysiological parameters have been found using waterstressed conditions data [17].

Positive and strong correlations and negative correlations were observed in the present study for yield components and other morphophysiological traits. Negative and significant correlations indicated that selection of a trait could decrease the expression of another (39). Molina et al., (34) assessed the water stress tolerance in three cultivars and seven lines of common bean, and they observed both positive and negative significant correlations for yield components. The findings, thus, showed that tolerance to water stress was related to $100 \mathrm{SW}, \mathrm{Chl} a, \mathrm{Chl} b$ and NPP. These results suggest that a selection method based on $100 \mathrm{SW}, \mathrm{Chl} a, \mathrm{Chl} b$ and NPP can be used in breeding for droughttolerant bean genotypes.

\section{Acknowledgement}

The authors are grateful to Dr. N. Phiri of the Seed Control and Certification Institute for providing the planting materials and advice. This work was part of the MSc. Plant Breeding and Seed Systems studies of the main author at the University of Zambia. The study was supported by a grant from the Alliance for Green Revolution in Africa (AGRA).

\section{References}

1. Beebe SE, Rao IM, Devi M and Polnia J. 2014. Common beans, biodiversity and multiple stresses: challenges of drought resistance in tropical soils. Crop and Pasture Science 65: 667675.

2. Emam Y, Shekoofa A, Salehi $\mathrm{F}$ and Jalali AH. 2010. Water stress effects on two common bean cultivars with contrasting growth habits. 9: 495- 499.

3. Broughton WJ, Hernandez G, Blair M, Beebe S, Gepts P, and Vanderleyden J. 2003. Beans (Phaseolus spp.) - model food legumes. Plant Soil 252: 55-128. 
4. Series, fodis information, food crop, and diversification Support. 2009. Growing beans in Zambia. Extension Pamphlet. Field Services, Zambia.

5. Wahid A, Gelani S, Ashraf M, Foolad MR. 2007. Heat tolerance in plants: An overview. Environmental and Experimental Botany 61: 199- 223.

6. Mataa, $\mathrm{M}$, and Tominaga S. 1998. The effects of shading stage and level on fruit set and development, leaf carbohydrates and photosynthesis in ponkan (Citrus reticulata Blanco). Japanese Journal of Tropical Agriculture. 42: 103- 110.

7. Mataa M, Mphande K. and Munyinda K. 2019. Interactive effects of phosphorus and water stress on plant development and yield resilience in common beans (Phaseolus vulgaris L.). African Journal of Agricultural Research. 14: 949- 962.

8. Namugwanya $M$, Tenywa JS, Otabbong E, Mubiru DN and Basamba TA. 2014. Development of common bean (Phaseolus vulgaris L.) production under low soil phosphorus and droughtinSubSaharan Africa: A review. Journal of Sustainable Development 5: 128- 139.

9. Jones HG. and JE. Corlett. 1992. Current topics in drought physiology. Journal of Agricultural Science 119: 291-296

10. Acosta-gallegos JA. and Domingo M. 2009. Adaptation traits in dry bean cultivars grown under drought stress. Características de adaptación en variedades de frijol Bajo Sequía 35: 416- 425.

11. Mukeshimana G, Lasley AL,
Loescher WH and Kelly JD. 2014. Identification of shoot traits related to drought tolerance in common bean seedlings. Journal of the American Society for Horticultural Science 139: 299- 309.

12. Suriyagoda LDB, Ryan, MH. Renton M and Lambers H. 2014. Plant responses to limited moisture and phosphorus availability: A meta- analysis. Advances in Agronomy, 124: 143- 200. http:// dx.doi.org/10.1016/B978-7.00048.

13. Larcher W, 2001. Physiological plant ecology: Ecophysiology and stress physiology of functional groups. 4th edition. Springer, pp: 513.

14. Xu H. Liu G. Liu G. Yan B. Duan, W. Wang L and S Li. 2014. Comparison of investigation of heat injury in grapevine (Vitis) and assessment of heat tolerance in different cultivars and species. BMC Plant Biol 14: 156. http:// doi.org/10.1186/1471-2229- 14156

15. Blum A. (1988): Plant breeding for stress environments, CRC Press: London.

16. ElBasyoni I, Saadalla M,Baenziger $\mathrm{S}$, Bockelman $\mathrm{H}$ and Morsey S. 2017. Cell membrane stability and association mapping for drought and heat tolerance worldwide wheat collection. Sustainability 9: 1606. https://doi.org/10.3390/su9091606

17. Nyarko G, Alderson P, Craigon G, J. Murchie E and Sparkes DL. 2008. Comparison of thermostability and chlorophyll flourescence parametres for the determination of heat tolerance in cabbage lines. Journal of Horticultural Science and Biotechnology 83: 678- 6782. 
18. Kandel H. 2010. Dry bean types and development stages. Plant Science. Issue 6.

19. Arnon D. 1949. Copper enzymes in isolated chloroplasts: polyphenol oxidases in Beta vulgaris. Plant Physiology 24: 1-15.

20. Karlidag H, Yildirin E, Turan M, Pehluvan, M, Donmez, F. 2013. Plant growth promoting rhizobacteria mitigate deleterious effects of salt stress on strawberry plants (Fragaria $x$ ananassa). HortSci. 48: 563-567.

21. Fischer RA, and Maurer R. 1978. Drought resistance in spring wheat cultivars. I. Grain yield responses. Aust. J. Agric. Res., 29: 897912.http:/dx.doi.org/10.1071/ AR9780897

22. Kristin AS, Serna R.R, Pérez F.I, Enríquez BC, Gallegos JAA, Vallejo P.R, Wassimi N, Kelley JD. 1997. Improving common bean performance under drought stress. Crop Sci. 37: 43-50.

23. SAS Institute, 1988. SAS/User's Guide, Release 6.03 ed., SAS Inst., Cary, NC, USA.

24. Taiz, L. and E. Zeiger. 2002. Plant physiology, 3rd edition. Senauer Assoc., Sunderland. MA. pp 690.

25. Ara N, Yang J Hu Z and Zhang M. 2013. Determination of heat tolerance of interspecific (Cucurbita maxima $x$ Cucurbita moschata) inbred line of squash 'Maxchata' and its parents through photosynthetic response. Journal of Agricultural Sciences. 19: 188- 197.

26. Baroowa B, and Gogoi N. 2012. Effect of induced drought on different growth and biochemical attributes of black gram (Vigna mungo L.) and green gram (Vigna radiata L.)" 6 [3].
27. MasaccioA,SM,Nabiev Pietrosanti L, Nematov SK, Chernikova $\mathrm{TN}$, Thor $\mathrm{K}$ and $\mathrm{J}$. Leipner. 2008. Response of photosynthetic apparatus of cotton (Gossypium hirsutum) to the onset of drought stress under field conditions studied by gas-exchange analysis and chlorophyll fluorescence imaging. Plant Physiology and Biochemistry 46: 189-195.

28. Kaiser WM, Prachuab G, Kaiser G, Wildmann SG, and Heber U, Photosynthesisunderosmoticstress. 1981Inhibition of photosynthesis of intact chloroplasts, protoplasts and leaf slices at high osmotic potentials, Planta, 153, 416-422.

29. Long SP, Humphries S and Falkowski PG. 1994. Photoinhibition of photosynthesis in nature, Annu. Rev. Plant Physiol. Plant Mol. Biol., 45: 633-662.

30. Wahid A, Gelani S, Ashraf M, MR Foolad. 2007. Heat tolerance in plants: An overview. Environmental and Experimental Botany 61: 199-223.

31. Pastori GM., Trippi, VS 1992. Oxidative stress induces high rate of glutathione reductase synthesis in a drought resistant maize strain. Plant Cell Physiol. 33: 957-961.

32. Jian Y, Liu H, Cline V. 2009. Correlations of leaf relative water content, canopy temperature and spectral reflectance in perennial ryegrass under water deficit conditions. HortScience, 44: 459-462.

33. Kumar A, Omae H, Egawa Y, Kashiwaba K and Shono M. 2006. JARQ, 40: 213.

34. Molina, JC, Moda-Carino V, N. Da Junior SF, De Faria RT and Destro D, 2001. Response of common bean cultivars and 
lines to water stress. Crop Breed.

Appl. Biotech., 1:363-372

35. Emam Y, 1985. Effects of $\mathrm{N}$ levels and moisture regimes on agronomic characteristics of four cultivars of dry beans (Phaseolus vulgaris L.). M.Sc Thesis. Shiraz University, Iran. Pp: 41. (in Farsi).

36. Teran H and SP Singh. 2002. Comparison of sources and selected lines for drought resistance in common beans. Crop Sci., 42: 6470.

37. Barrios, A., Hoogenboom, and G., Nesmith DS. 2005. Drought stress and the distribution of vegetative and reproductive traits of a bean cultivar. Sci. Agric. (Piracicaba, Braz.). 62: 18-22.

38. Agili SB, Nyende K, Ngamau, and Masinde P. 2012. Nutrition and food selection, yield evaluation, drought tolerance indices of orange-flesh sweetpotato (Ipomoea Batatas Lam) hybrid clone, 2: 2- 9. doi:10.4172/2155-9600.1000138.

39. Ramalho MAP, Santos JB and Zimmermann MJO 1993. Genetica quantittaiva en plantas autogamas: Aplicacoes ao melhoramento de feijoeiro. UFG, Goiania. p271. 
Table 2: Means of water stress regimes and genotypes for morphophysiological traits of common bean grown at Nanga, Zambia during the 2012 season

\begin{tabular}{|c|c|c|c|c|c|c|c|}
\hline Genotype & $\begin{array}{l}\text { Stress } \\
\text { level }^{\mathrm{z}}\end{array}$ & $\begin{array}{l}\text { Cell membrane } \\
\text { Thermostability }\end{array}$ & Chl a $a^{y}$ & Chl b $b^{x}$ & Total Chlw & $\begin{array}{l}\text { Relative } \\
\text { water } \\
\text { height } \\
\text { content }\end{array}$ & Plant \\
\hline & & $(\%)$ & $\left(\mathrm{mg} \mathrm{g}^{-1}\right)$ & $\left(\mathrm{mg} \mathrm{g}^{-1}\right)$ & $\left(\mathrm{mg} \mathrm{g}^{-1}\right)$ & $\begin{array}{c}(\%) \\
(\mathrm{cm})\end{array}$ & \\
\hline \multirow{3}{*}{ CAR-ZAR } & High & $44.2(0.57)^{\mathrm{v}}$ & $8.7(1.2)^{\mathrm{u}}$ & 7.1 & $15.8(0.50)^{\mathrm{t}}$ & 77 & 12 \\
\hline & Low & $58.5(0.76)$ & $8.6(0.50)$ & 17.2 & $25.8(0.81)$ & 84 & 20 \\
\hline & $\begin{array}{l}\text { No } \\
\text { stress }\end{array}$ & 77.1 - & $9.8(0.45)$ & 21.9 & $31.7-$ & 83 & 20 \\
\hline \multirow[t]{3}{*}{ Gadra } & High & $31.7(0.56)$ & $4.9(0.90)$ & 5.4 & $10.3(0.42)$ & 77 & 14 \\
\hline & Low & $47.9(0.84)$ & $9.0(0.64)$ & 13.9 & $22.9(0.94)$ & 83 & 19 \\
\hline & $\begin{array}{l}\text { No } \\
\text { stress }\end{array}$ & $56.8-$ & $11.9(0.96)$ & 12.4 & $24.3-$ & 89 & 19 \\
\hline \multirow[t]{3}{*}{ KE 3} & High & $57.5(0.93)$ & $9.3(0.46)$ & 20.0 & $29.3(0.74)$ & 76 & 24 \\
\hline & Low & $61.8(0.99)$ & $10.4(0.44)$ & 23.7 & $34.1(0.86)$ & 83 & 26 \\
\hline & $\begin{array}{l}\text { No } \\
\text { stress }\end{array}$ & $62.1-$ & $17.2(0.78)$ & 22.2 & $39.4-$ & 88 & 33 \\
\hline \multirow[t]{3}{*}{ KE 4} & High & $59.7(0.84)$ & $5.0(0.78)$ & 6.4 & $11.4(0.33)$ & 72 & 22 \\
\hline & Low & $61.4(0.86)$ & $9.1(0.97)$ & 9.4 & $18.5(0.54)$ & 80 & 30 \\
\hline & $\begin{array}{l}\text { No } \\
\text { stress }\end{array}$ & $71.3-$ & $17.8(1.06)$ & 16.7 & $34.5-$ & 85 & 40 \\
\hline \multirow[t]{3}{*}{ SER 180} & High & $37.5(0.65)$ & $8.4(0.49)$ & 16.5 & $24.9(0.59)$ & 80 & 22 \\
\hline & Low & $53.5(0.93)$ & $9.6(0.43)$ & 22.2 & $31.8(0.76)$ & 90 & 25 \\
\hline & $\begin{array}{l}\text { No } \\
\text { stress }\end{array}$ & $57.8-$ & $16.9(0.67)$ & 25.0 & 41.9 - & 93 & 40 \\
\hline \multirow[t]{3}{*}{ SER 76} & High & $52.5(0.84)$ & $9.4(1.06)$ & 8.8 & $18.2(0.52)$ & 78 & 23 \\
\hline & Low & $57.7(0.92)$ & $11.1(0.59)$ & 18.6 & $29.7(0.86)$ & 89 & 25 \\
\hline & $\begin{array}{l}\text { No } \\
\text { stress }\end{array}$ & $62.7-$ & $15.9(0.84)$ & 19.0 & $34.9-$ & 85 & 25 \\
\hline \multirow[t]{3}{*}{ SER 89} & High & $51.7(0.83)$ & $5.6(0.95)$ & 5.8 & $11.4(0.28)$ & 82 & 20 \\
\hline & Low & $54.6(0.88)$ & $10.9(0.52)$ & 20.8 & $31.7(0.78)$ & 90 & 33 \\
\hline & $\begin{array}{l}\text { No } \\
\text { stress }\end{array}$ & 62.0 & $14.4(0.55)$ & 26.2 & 40.6 - & 91 & 38 \\
\hline \multirow[t]{3}{*}{ ZM 4488} & High & $57.3(0.89)$ & $9.5(0.49)$ & 13.3 & $22.8(0.43)$ & 59 & 16 \\
\hline & Low & $65.3(1.00)$ & $10.6(0.63)$ & 16.9 & $27.5(0.52)$ & 87 & 19 \\
\hline & $\begin{array}{l}\text { No } \\
\text { stress }\end{array}$ & $64.7-$ & $14.8(0.39)$ & 37.9 & $52.7-$ & 85 & 32 \\
\hline LSD@ 5\% & & 1.13 & 0.56 & 0.76 & 1.66 & 1.4 & 0.5 \\
\hline CV $(\%)$ & & 3.0 & 5.8 & 5.1 & 3.9 & 7.1 & 2.0 \\
\hline
\end{tabular}

${ }^{2}$ Water stress level indicated as evapo transpiration.

${ }^{\mathrm{y}} \mathrm{Chl} \mathrm{a:} \mathrm{Chlorophyll} \mathrm{content} \mathrm{a} \mathrm{(figure} \mathrm{in} \mathrm{parenthesis} \mathrm{is} \mathrm{the} \mathrm{proportion} \mathrm{of} \operatorname{chl} a$ to $\operatorname{chl} b$ ).

${ }^{\mathrm{x}} \mathrm{Chl}$ b: Chlorophyll content.

wFigure in parenthesis is the proportion of Chlorophyll in stressed plots to total Chlorophyll.

${ }^{v}$ Cell membrane thermosenstivity. 


\begin{tabular}{|c|c|c|c|c|c|c|c|}
\hline Genotype & Stress level ${ }^{\mathrm{z}}$ & $\begin{array}{l}\text { Yield }^{y} \\
\left(\mathrm{~kg} \mathrm{ha}^{-1}\right)\end{array}$ & $\mathrm{NN}^{\mathrm{x}}$ & $\begin{array}{l}\text { Number } \\
\text { of pods } \\
\text { per plant }\end{array}$ & $\begin{array}{l}\text { Number } \\
\text { of seeds } \\
\text { per plant }\end{array}$ & $\begin{array}{l}100 \text { seed } \\
\text { weight } \\
\text { (g) }\end{array}$ & DTFw $^{w}$ \\
\hline \multirow{3}{*}{ CAR-ZAR } & High stress & $559.8(32.1)$ & 6 & 12 & 4 & 27 & 50 \\
\hline & Low stress & $493.2(28.3)$ & 8 & 25 & 4 & 45 & 48 \\
\hline & Non stressed & 1741 & 8 & 37 & 7 & 51 & 61 \\
\hline \multirow[t]{3}{*}{ Gadra } & High stress & $1320(80.9)$ & 5 & 22 & 4 & 36 & 50 \\
\hline & Low stress & $1610.6(98.7)$ & 6 & 20 & 4 & 38 & 49 \\
\hline & Non stressed & 1631.9 & 8 & 35 & 6 & 46 & 59 \\
\hline \multirow[t]{3}{*}{ KE 3} & High stress & $616.2(24.8)$ & 7 & 15 & 4 & 38 & 50 \\
\hline & Low stress & 860.7 (34.6) & 8 & 16 & 5 & 41 & 48 \\
\hline & Non stressed & 2489.6 & 9 & 22 & 5 & 42 & 53 \\
\hline \multirow[t]{3}{*}{ KE 4} & High stress & $1499.3(67.0)$ & 6 & 18 & 4 & 43 & 50 \\
\hline & Low stress & $1506(67.3)$ & 7 & 21 & 5 & 47 & 55 \\
\hline & Non stressed & 2236.3 & 10 & 23 & 6 & 47 & 62 \\
\hline \multirow[t]{3}{*}{ SER 180} & High stress & $645.8(45.0)$ & 5 & 23 & 4 & 27 & 35 \\
\hline & Low stress & 855.8 (59.7) & 6 & 32 & 4 & 29 & 38 \\
\hline & Non stressed & 1433.8 & 9 & 36 & 6 & 41 & 54 \\
\hline \multirow[t]{3}{*}{ SER 76} & High stress & $812.2(18.6)$ & 6 & 22 & 5 & 24 & 50 \\
\hline & Low stress & 902.9 (20.7) & 7 & 27 & 5 & 35 & 52 \\
\hline & Non stressed & 4363.7 & 8 & 42 & 5 & 47 & 62 \\
\hline \multirow[t]{3}{*}{ SER 89} & High stress & $672.1(34.6)$ & 6 & 14 & 4 & 23 & 36 \\
\hline & Low stress & $1137.3(59.7)$ & 8 & 23 & 4 & 42 & 47 \\
\hline & Non stressed & 1904.5 & 9 & 31 & 5 & 43 & 61 \\
\hline \multirow[t]{3}{*}{ ZM 4488} & High stress & $803.9(46.5)$ & 7 & 16 & 4 & 32 & 36 \\
\hline & Low stress & $1259.4(72.8)$ & 8 & 21 & 4 & 39 & 34 \\
\hline & Non stressed & 1729.7 & 9 & 34 & 6 & 47 & 54 \\
\hline $\begin{array}{l}\operatorname{LSD}(5 \%) \\
\text { CV(\%) }\end{array}$ & & $\begin{array}{l}32.3 \\
2.6\end{array}$ & $\begin{array}{l}.5 \\
7.1\end{array}$ & $\begin{array}{l}0.9 \\
4.3\end{array}$ & $\begin{array}{l}0.9 \\
10.7\end{array}$ & $\begin{array}{l}0.8 \\
2.3\end{array}$ & $\begin{array}{l}0.9 \\
2.0\end{array}$ \\
\hline
\end{tabular}

${ }^{2}$ Water stress level indicated as evapo transpiration; High stress $=50 \%$, Low stress $=75 \%$ and Non stresses $=100 \%$.

${ }^{y}$ Numbers in parenthesis represent yield for stressed plots expressed as a percentage of non- stressed treatments

${ }^{\mathrm{x} N \mathrm{~N}}$; Number of nodes per plant.

${ }^{\mathrm{w}}$ DTF $50 \%$ : days to $50 \%$ Flowering. 
Table 4: Comparison of mean seed yield of eight genotypes in stressed and nonstressed environments. Plants were stressed up to 50 per cent

\begin{tabular}{llllll}
\hline Genotypes & $\begin{array}{l}\text { Yield of } \\
\text { non- stressed } \\
\text { treatment } \\
\left(\text { ton ha }{ }^{-1}\right)\end{array}$ & $\begin{array}{l}\text { Yield of } \\
\text { stressed } \\
\text { treatments } \\
\left(\text { ton } \mathrm{ha}^{-1}\right)\end{array}$ & $\begin{array}{l}\text { Percentage } \\
\text { yield } \\
\text { reduction } \\
(\%)\end{array}$ & $\begin{array}{l}\text { Drought } \\
\text { susceptibility } \\
\text { Index }\end{array}$ & $\begin{array}{l}\text { Geometric } \\
\text { mean } \\
\left.\text { (ton ha }{ }^{-1}\right)\end{array}$ \\
\hline Gadra & 1.63 & 1.32 & 19.1 & 0.3 & 1.47 \\
KE 4 & 2.24 & 1.50 & 33.0 & 0.5 & 1.83 \\
ZM 4488 & 1.73 & 0.80 & 53.5 & 0.9 & 1.18 \\
SER 180 & 1.43 & 0.65 & 55.0 & 0.9 & 0.96 \\
SER 89 & 1.90 & 0.67 & 64.7 & 1.1 & 1.13 \\
CAR-ZAR & 1.74 & 0.56 & 67.9 & 1.1 & 0.99 \\
KE 3 & 2.49 & 0.62 & 75.3 & 1.2 & 1.24 \\
SER 76 & 4.36 & 0.81 & 81.4 & 1.3 & 1.88 \\
\hline $\begin{array}{l}\text { Grand } \\
\text { mean }\end{array}$ & 2.19 & 0.87 & 56.2 & & \\
\hline
\end{tabular}

Table 5: Effect of water stress applied on 8 bean genotypes on morphophysiological traits of common bean genotypes. Data was pooled across genotypes

\begin{tabular}{|c|c|c|c|c|c|c|c|}
\hline $\begin{array}{l}{ }^{2} \text { Water } \\
\text { Regime }\end{array}$ & & $\begin{array}{l}\mathrm{Chl} \mathrm{a}^{\mathrm{x}} \\
\left(\mathrm{mg} \mathrm{g}^{-1}\right)\end{array}$ & & $\begin{array}{l}\mathrm{Ch} \mathrm{lb}^{\mathrm{w}} \\
\left(\mathrm{mg} \mathrm{g-}^{1}\right)\end{array}$ & $\begin{array}{l}\text { Tot } \mathrm{Chl}^{\mathrm{s}} \\
\left(\mathrm{mg} \mathrm{g-}^{1}\right)\end{array}$ & $\begin{array}{l}\text { Relative } \\
\text { water } \\
\text { content } \\
(\%)\end{array}$ & $\begin{array}{l}\text { Plant height } \\
(\mathrm{cm})\end{array}$ \\
\hline WR $1(50 \%)$ & 7.6 & 10.4 & 18 & 75 & & 19 & \\
\hline WR 2 (75\%) & 9.9 & 17.8 & 27.7 & 86 & & 24 & \\
\hline Normal & 14.8 & 22.7 & 37.5 & 87 & & 31 & \\
\hline $\operatorname{LSD}(5 \%)$ & 0.56 & 0.76 & 3.9 & 1.4 & & 0.5 & \\
\hline
\end{tabular}

${ }^{2}$ Water stress level indicated as evapo transpiration.

${ }^{x} \mathrm{Chl}$ a: Chlorophyll content a;

${ }^{w} \mathrm{Chl}$ b: Chlorophyll content b;

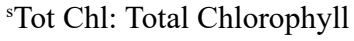


Table 6: Stepwise multiple regression of yield on morphophysiological traits

\begin{tabular}{lcccc}
\hline Variable & $\begin{array}{l}\text { Partial } \\
\text { Square }\end{array}$ & $\begin{array}{l}\text { R- Model } \\
\text { Square }\end{array}$ & R-F-Value & Pr $>$ F \\
\hline & & & & \\
$\mathrm{HSW}^{\mathrm{s}}$ & 0.373 & 0.373 & 55.9 & 0.000 \\
$\mathrm{Chla}^{\mathrm{w}}$ & 0.117 & 0.490 & 21.354 & 0.000 \\
$\mathrm{Chlb}^{\mathrm{x}}$ & 0.068 & 0.558 & 14.217 & 0.000 \\
$\mathrm{NPP}^{\mathrm{y}}$ & 0.090 & 0.648 & 23.130 & 0.000 \\
$\mathrm{NN}^{\mathrm{z}}$ & 0.30 & 0.678 & 8.375 & 0.005 \\
\hline
\end{tabular}

sHSW: Hundred seed weight;

${ }^{\text {w } C h l a: ~ C h l o r o p h y l l ~ a ~ c o n t e n t ; ~}$

${ }^{x}$ Chlb: Chlorophyll b content;

NPP: Number of pods per plant;

${ }^{z} \mathrm{NN}$ : Number of nodes per plant. 